\title{
KREATIVITAS, SIKAP TERHADAP KEWIRAUSAHAAN, ORIENTASI KEWIRAUSAHAAN UNTUK MEMPREDIKSI NIAT BERWIRAUSAHA PADA MAHASISWA UNIVERSITAS TARUMANAGARA
}

\author{
Jesslyn Natasha Halim dan Kartika Nuringsih \\ Program Studi Manajemen Fakultas Ekonomi dan Bisnis \\ Universitas Tarumanagara, Jakarta \\ Email: jesslyn.115169108@stu.untar.ac.id
}

\begin{abstract}
The purpose of this study was to determine the effect of creativity, attitudes towards entrepreneurship, entrepreneurial orientation on entrepreneurial intentions of Tarumanagara University students in Jakarta. The samples used in this research were 100 respondents who were students of Tarumanagara University in Jakarta and use technique for judgemental sampling choosing the respondents. This research uses Smart Partial Least Square (PLS) software version 3.0 as a data analysis method. The results of this research indicates that attitude towards entrepreneurship and entrepreneurial orientation affects the entrepreneurial intention, while the creativity does not affect the entrepreneurial intention.
\end{abstract}

Keywords: Creativity, attitudes towards entrepreneurship, entrepreneurial orientation, entrepreneurial intention

Abstrak: Penelitian ini bertujuan mengetahui pengaruh kreativitas, sikap terhadap kewirausahaan, dan orientasi kewirausahaan terhadap niat berwirausahaa pada mahasiswa Universitas Tarumanagara di Jakarta. Sampel yang digunakan dalam penelitian ini sebanyak 100 responden yang merupakan mahasiswa/i Universitas Tarumanagara di Jakarta sedangkan teknik pemilihan sampel menggunakan judgemental sampling. Selanjutnya, studi ini menggunakan Software Smart Partial Least Square (PLS) versi 3.0 sebagai alat untuk mengolah data dengan teknik analisis menggunakan pendekatan regresi. Hasil penelitian menunjukkan sikap terhadap kewirausahaan dan orientasi kewirausahaan berpengaruh terhadap niat berwirausaha, sedangkan kreativitas tidak memiliki pengaruh terhadap niat berwirausaha.

Kata kunci: Kreativitas, sikap terhadap kewirausahaan, orientasi kewirausahaan, niat berwirausaha

\section{LATAR BELAKANG}

Banyak pengangguran dan rendahnya tingkat wirausaha di Indonesia terjadi lantaran belum ada dukungan dari pemerintah maupun swasta. Beberapa faktor yang menjadi alasan adalah pola berpikir dari masyarakat yang cenderung lebih mencari pekerjaan dan terkendala dalam persoalan modal. Menjadi seorang wirausaha harus memiliki keberanian untuk keluar dari zona nyaman dan diharuskan untuk berpikir kreatif dan inovatif. Menurut mentri perdagangan Enggartiasto Lukita pada Oktober 2018 mengatakan tingkat kewirausahaan Indonesia masih rendah dan hanya menduduki peringkat 94 dari 137 negara. Di Negara maju rata-rata 14 persen dari jumlah total penduduknya adalah entrepreneur sedangkan di Indonesia tingkat entrepreneur hanya berjumlah 3,1 persen. Ia juga mengatakan salah satu 
penyebab rendahnya tingkat entrepreneur di Indonesia karena system pendidikan yang kurang mendorong mahasiswa untuk berkembang menjadi seorang entrepreneur yang sukses dan dapat membuat trobosan baru untuk menciptakan lapangan pekerjaan saat ini.

Seorang entrepreneur saat ini masih di pandang sebelah mata oleh masyarakat. Berwirausaha dianggap sebuah profesi yang kurang menjanjikan dan perlu waktu lama untuk bisa menjadi seorang entrepreneur yang sukses. Saat ini masih banyak lulusan sarjana melamar menjadi karyawan swasta dan PNS ( Pegawai Negri Sipil) dibandingkan memanfaatkan dan menerapkan ilmu pengetahuannya yang diperoleh dari kuliah untuk menciptakan lapangan kerja baru, minimal untuk dirinya sendiri. Entrepreneurship patut didorong karena memiliki potensi besar, karena Indonesia dengan bonus demografi dan kekayaan alam, bisa mengembangkan diri menjadi suatu komunitas entrepreneurship. Adapun Tingkat Pengangguran Terbuka (TPT) berdasarkandata resmi dari Badan Pusat Statistik (BPS) mencapai 7,05 juta orang per Agustus 2019. Data Global Entrepreneurship Index, Indonesia menempati peringkat 94 dunia dari 137 negara. Indonesia menempati peringkat 94 sedangkan posisi ini jauh di bawah Negara ASEAN lainnya seperti Singapura, Malaysia, Thailand,dan Filipina yang masing-masing menempati peringkat 27,58,71, dan 84 . Hal ini masih menunjukkan bahwa Tingkat wirausaha di Indonesia masih rendah. Jumlah pengangguran di Indonesia dari tahun ke tahun terus meningkat, hal ini disebabkan karena sedikitnya lapangan pekerjaan sedangkan jumlah lulusan perguruan tinggi selalu bertambah. Kondisi tersebut diperparah lagi dengan adanya ( Pemutusan Hubungan Kerja) PHK dari beberapa perusahaan yang mengalami kebangkrutan. Masalah ini sebenarnya dapat diatasi apabila Negara mampu menyediakan lapangan kerja sebanyak mungkin. Namun hal ini tidak dapat terealisasi dengan cepat, karena banyaknya kendala baik dari segi ekonomi maupun sumber daya manusia itu sendiri. Edukasi terhadap kewirausahaan bisa di mulai pada saat di bangku sekolah yang merupakan tempat dimana seseorang belajar menjadi seorang entrepreneur demikian pula perguruan tinggi menjadi peluang bagi mahasiswa-mahasiswi untuk belajar mengenai jiwa kewiraushaan sekaligus melakukan praktik-praktik kewirausahaan. Fakultas Ekonomi dan Bisnis Universitas Tarumanagara menjadi salah satu tempat untuk meningkatkan kemauan mahasiswa dan mahasiswi nya untuk menjadi seorang entrepreneur.

Fakultas Ekonomi dan Bisnis Universitas Tarumanagara kewirausahaan menjadi salah satu konsentrasi pilihan yang ditawarkan untuk mendorong terciptanya seorang wirausahawan yang baru. Fakultas Ekonomi dan Bisnis Universitas Tarumanagara menyelenggarakan sebuah program yang dinamakan Entrepreneur Week sebagai salah satu kegiatan mahasiswa Fakultas Ekonomi dan Bisnis untuk memprekenalkan produk dari Bussines Plan yang sudah dibuat agar berani berwirausaha. Karena pendidikan yang ditawarkan oleh Universitas sangat mempengaruhi pemilihan karir Mahasiswanya, Universitas dapat dilihat sebagai salah satu sumber yang potensial dan merupakan program mendukung Mahasiswa untuk berani mencoba sesuatu yang sebelumnya belum pernah dilakukan, pendidikan juga merupaka faktor pendukung agar dapat mengerti bagaimana cara memulai sebuah wirausaha yang benar dan juga yang dapat berkembang dalam berwirausaha. Selain dari pendidikan ada beberapa hal yang dapat membangun niat dalam berwirausaha yaitu kreativitas, sikap terhadap kewirausahaan, dan juga orientasi kewirausahaan yang ada pada Mahasiswa juga dapat menjadi hal yang dapat membangun niat berwirausaha Mahasiswa. Menurut (Fatoki, 2010) salah satu alasan teoritis untuk keterkaitan ini adalah bahwa persepsi diri tentang kreativitas bertindak sebagai motivator untuk mengejar karir kewirausahaan sedangkan Menurut (Giacomin et al., 2011) Niat berwirausaha, serta sikap positif terhadap wirausahawan, seharusnya menjadi bagian motivasi penting dari aktivitas 
kewirausahaan. Selain itu Terkait dengan Orientasi kewirausahaan Schumpeter (1928) menghubungkan peran wirausahawan dengan penghancuran kreatif dengan mengubah sistem produksi yang ada. Sedangkan menurut Kirzner (1978) dalam teorinya tentang kewirausahaan menyimpulkan bahwa wirausahawan adalah kekuatan pendorong di pasar karena perannya dalam menemukan peluang yang tidak terpakai di pasar, dan perilaku kompetitif wirausahawan bersifat operasional dalam memulihkan keseimbangan. Wirausaha inovatif yang dijelaskan oleh Schumpeter lebih terkait dengan memperkenalkan ide bisnis kreatif yang dapat mengubah sifat pasar, sedangkan wirausaha yang dijelaskan oleh Kirzner lebih merupakan pencari peluang yang mampu melihat celah pasar dan kesalahan yang dilakukan oleh pengusaha lain dalam situasi informasi yang tidak lengkap. Selain itu Orientasi kewirausahaan (EO) adalah orientasi strategis tingkat perusahaan yang menangkap praktik pembuatan strategi organisasi, filosofi manajerial, dan perilaku perusahaan yang bersifat kewirausahaan. Orientasi kewirausahaan telah menjadi salah satu konstruksi yang paling mapan dan diteliti dalam literatur kewirausahaan Kesamaan umum di antara konseptualisasi EO masa lalu adalah dimasukkannya inovasi, proaktif, dan pengambilan risiko sebagai aspek inti yang menentukan atau dimensi orientasi. Secara umum, para ahli teori tidak akan menyebut perusahaan sebagai wirausaha jika itu mengubah teknologi atau lini produknya hanya dengan meniru langsung pesaing sambil menolak mengambil risiko. Orientasi kewirausahaan (entrepreneurial orientation) adalah orientasi perusahaan yang memiliki prinsip pada upaya untuk mengidentifikasi dan mengeksploitasi kesempatan (Lee \& Chu, 2011). kewirausahaan dan orientasi pasar merupakan orientasi yang saling melengkapi, sehingga kewirausahaan memerlukan orientasi pasar untuk menargetkan tindakan inovatifnya agar berhasil di pasar, dan orientasi pasar memerlukan kewirausahaan untuk mendapatkan tanggapan yang cepat terhadap peluang pasar. Kemajuan penting dalam pemahaman kita tentang perilaku kewirausahaan adalah orientasi kewirausahaan (EO) (Rauch et al 2009).

Menurut (Nuringsih et.al., 2019) Melalui pendidikan diharapkan dapat meningkatkan pengetahuan sosial sehingga dapat menginspirasi mahasiswa berwirausaha untuk menyelaraskan dengan profit dan orientasi orang. Temuan menunjukkan bahwa harapan dan level mahasiswa tidak memoderasi hubungan antara kepribadian proaktif dan intensi kewirausahaan. Sedangkan status pekerjaan dan efikasi diri secara signifikan memoderasi hubungan antara kepribadian proaktif dan intensi kewirausahaan sehingga mahasiswa proaktif yang bekerja akan memiliki niat lebih tinggi menjadi wirausaha daripada mereka yang tidak bekerja. Penelitian ini penting untuk dilakukan dengan adanya beberapa kesenjangan yang ditemukan pada penelitian sebelumnya. Pada penelitian-penelitian terdahulu lebih banyak mengkaji mengenai faktor yang mempengaruhi intensi kewirausahaan mahasiswa, di mana tampak variasi dari faktor yang mempengaruhi intensi kewirausahaan mahasiswa. Dalam menjalankan sebuah usaha hal yang harus di perhatikan adalah niat berwirausaha dari seorang wirausaha untuk memulai suatu dengan komitmen yang kuat.. Menurut Molaei et al. (2014), niat kewirausahaan merupakan salah satu prediktor terbesar dari perilaku kewirausahaan; Oleh karena itu, pertimbangan khusus harus diberikan untuk mengeksplorasi penyebab di balik niat berwirausaha siswa. Dari perspektif wirausahawan potensial, seperti mahasiswa, kewirausahaan dimulai dengan ide (Hayton dan Cholakova, 2012). Menurut Thompson (2009) dan Bird (1988) niat kewirausahaan dapat disebut sebagai realisasi dan keyakinan yang disengaja dari seseorang sehubungan dengan niatnya untuk memulai usaha bisnis baru di masa depan. Menurut (kartika et.al.,2019) Niat dalam berwirausaha berkelanjutan adalah sebagai keinginan untuk berlatih memulai yang baru bisnis yang menguntungkan dan didasarkan pada barang dan jasa yang manfaat lingkungan dan melestarikan budaya sosial atau kearifan lokal di sekitarnya pengusaha. Ini 
mencerminkan indikasi seberapa keras orang mau mencoba bisnis model yang sejalan dengan keberlanjutan. Niat berwirausaha juga merupakan faktor penting untuk menumbuhkan perilaku kewirausahaan, sehingga dalam pembelajaran kewirausahaan, sangat penting untuk meningkatkan niat berwirausaha Mahasiswa dengan adanya sarana yang di berikan oleh Universitas Tarumanagara dapat membantu dalam membangun niat berwirausaha Mahasiswa dengan adanya praktek yang di lakukan dalam belajar membuka sebuah usaha seperti entrepreneurs week yang di lakukan dan juga memberikan seminar dengan para professional yang di dukung oleh Universitas Tarumanagara.

Dengan demikian studi ini menekankan pada tiga aspek yaitu kreativitas, sikap terhadap kewirausahaan, ortientasi kewirausahaan untuk dianalisis pengaruhnya terhadap niat berwirausaha pada mahasiswa di Universitas Tarumanagara.

\section{KAJIAN TEORI}

Teori yang menjadi dasar dalam penelitian ini adalah Theory of Planned Behavior (TPB) adalah "Hubungan antara niat dan tindakan dijelaskan oleh, teori psikologi sosial tentang perilaku terencana (Ajzen, 1991)". dalam TPB, niat ditentukan oleh tiga variabel, yaitu: Attitude (Sikap) : Sikap merupakan suatu faktor dalam diri seseorang yang dipelajari untuk memberikan respon positif atau negatif pada penilaian terhadap sesuatu yang diberikan. Subjective Norm (Norma Subjektif) : Subjective norm (norma subjektif) merupakan persepsi seseorang tentang pemikiran orang lain yang akan mendukung atau tidak mendukungnya dalam melakukan sesuatu. Perceived Behavioral Control (Kontrol Perilaku) : Kontrol perilaku adalah persepsi kemudahan atau kesulitan dalam melakukan suatu perilaku. Kewirausahaan juga merupakan suatu kreativitas, sikap, dan kemampuan dalam menciptakan sesuatu hal baru yang dapat menjadi Mahasiswa Universitas Tarumanagara Belajar untuk mengerti pentingnya kewirausahaan untuk menciptakan sesuatu yang unik. Pengusaha memainkan peran penting dalam membangun dan memelihara pembelajaran organisasi dan memulai perubahan (Drucker, 1985; Garc1'a-Morales et al., 2006). Mengembangkan keterampilan yang terlibat dalam mengidentifikasi peluang bisnis memiliki peran penting dalam upaya kewirausahaan (Rae, 2007; Heinonen dan Poikkijoki, 2006.

Kreativitas merupakan kemampuan yang dimiliki seseorang untuk menemukan dan menciptakan suatu hal baru,cara-cara baru, model baru, yang berguna. Menurut (Fatoki, 2010) salah satu alasan teoritis untuk keterkaitan ini adalah bahwa persepsi diri tentang kreativitas bertindak sebagai motivator untuk mengejar karir kewirausahaan. Dapat disimpulkan bahwa dengan adanya kreativitas, dapat memotivasi mahasiswa/i dalam berwirausaha Dalam Penelitian yang dilakukan (Lee dan Wong, 2004) Dapat diperdebatkan bahwa orang-orang kreatif, dibandingkan dengan orang yang kurang kreatif, lebih cenderung tertarik oleh peluang kerja yang memungkinkan mereka mengembangkan potensi kreatif mereka, dan lebih cenderung menggunakan keterampilan mereka untuk memanfaatkan ideide bisnis yang baik. Hamidi et al. (2008) menemukan bahwa pengaruh kreativitas pada niat kewirausahaan lebih kuat daripada pengaruh kontrol perilaku yang dipersepsikan, norma sosial yang dipersepsikan, dan kecenderungan mengambil risiko. Berdasarkan keterkaitan tersebut kreativitas merupakan hal yang dibutuhkan untuk memotivasi untuk mengeluarkan ide-ide yang baru dalam berwirausaha dan juga membangun niat dalam berwirausaha.

Dengan demikian, dapat dirumuskan hipotesis:

H1: Kreativitas berpengaruh positif terhadap Niat berwirausaha. 
Kreativitas adalah kemampuan untuk menciptakan sesuatu yang baru, baik yang benar-benar merupakan hal baru atau sesuatu ide baru yang diperoleh dengan cara menghubungkan beberapa hal yang sudah ada dan menjadikannya suatu hal baru. Selain itu, kreativitas adalah hal-hal yang membuat kita takjub dengan hal-hal baru, karena kreativitas bisa mewujudkan ide-ide cemerlang. Kreativitas merupakan salah satu yang mempengaruhi niat dalam berwirausaha. Seseorang yang kreatif dapat berinovasi dan mencari informasi tentang perkembangan yang ada dengan memperbaharui pengetahuan yang sebelumnya ada. Dapat diperkuat dengan adanya pendapat dari (Runco and Jaeger, 2012) "Creativity is commonly described as the capacity to create objects or ideas that are novel and effective" Kreativitas biasanya digambarkan sebagai kemampuan untuk menciptakan objek atau ide yang baru dan efektif. Berdasarkan keterkaitan tersebut maka kreativitas kewirausahaan dibutuhkan untuk membantu mahasiswa menjadikan niat dalam berwirausaha semankin bertambah.

H2: Sikap terhadap kewirausahaan berpengaruh positif terhadap Niat berwirausha.

Sikap adalah pernyataan evaluatif terhadap objek, orang atau peristiwa. Menurut Douglas dan Shepherd (2002) menemukan bahwa sikap yang lebih positif terhadap risiko dan kemandirian mengarah pada niat kewirausahaan yang lebih kuat. Dapat disimpulkan dengan adanya sikap yang positif terhadap kemadirian dapat meningkatkan niat dalam berwirausaha. Memperkenalkan kewirausahaan kepada siswa dalam lingkungan pendidikan memfasilitasi pengembangan sikap yang mendukung kewirausahaan dan pendidikannya (Pulka et al., 2014), sikap dan niat kewirausahaan yang lebih positif (Kolvereid dan Isaksen, 2006). Dengan adanya pengembangan terhadap sikap mahasiswa dapat mendukung dalam membangun niat berwirausaha mahasiswa. Menurut (Giacomin et al., 2011) Niat berwirausaha, serta sikap positif terhadap wirausahawan, seharusnya menjadi bagian motivasi penting dari aktivitas kewirausahaan. Berdasarkan keterkaitan tersebut maka sikap terhadap kewirausahaan dibutuhkan untuk membantu mahasiswa menjadikan niat dalam berwirausaha semankin kuat dengan sikap yang positif.

H3: Orientasi kewirausahaan berpengaruh positif terhadap Niat bewiraushaan.

Berikut gambar 1. menunjukkan kerangka pemikiran yang diajukan sebagai berikut: Menurut penelitian Lumpkin dan Dess (1996) mengemukakan bahwa orientasi kewirausahaan antara individu dan organisasi dapat dikembangkan melalui pangsa pasar, penjualan dan komitmen. Dapat disimpulkan bahwa dengan adanya orientasi kewirausahaan memperkuat komitmen dari seorang wirausahawan. Dalam penelitian oleh Wang (2008) mengemukakan gagasan tentang orientasi kewirausahaan, sebagai komponen fundamental dari keberhasilan setiap usaha. Sedangkan, Menurut Simon et al. (2011), komitmen dapat memberikan manfaat bagi perusahaan, mengatasi masalah yang terkait dengan orientasi kewirausahaan. Berdasarkan keterkaitan tersebut maka Orientasi kewirausahaan dibutuhkan untuk menumbuhkan niat berwirausaha dan berkomitmen dalam menjalankan sebuah usaha.

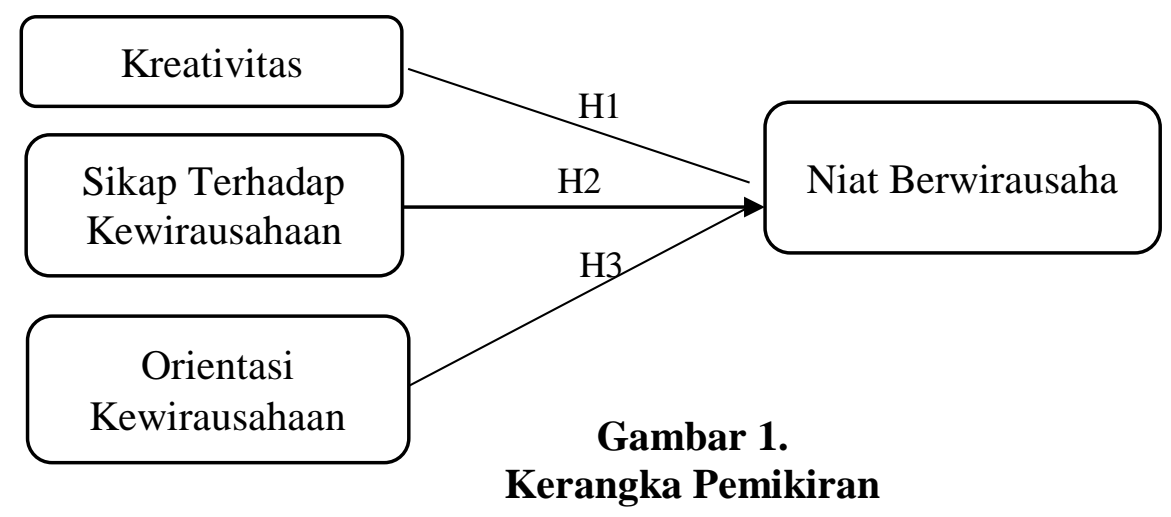




\section{METODOLOGI}

Metodologi adalah analisis teoritis sistematis dari metode yang diterapkan pada bidang studi. Ini terdiri dari analisis teoritis dari tubuh metode dan prinsip-prinsip yang terkait dengan cabang pengetahuan selain itu metodologi penelitian adalah cara atau teknik yang disusun secara teratur yang digunakan oleh seorang peneliti untuk mengumpulkan data/informasi dalam melakukan penelitian yang disesuaikan dengan subjek/objek yang diteliti. Menurut Punaji (2010) Penelitian deskriptif merupakan penelitian yang bertujuan untuk dapat menjelaskan suatu keadaan peristiwa atau segala hal yang dapat berkaitan dengan variabelvariabel yang dapat dijelaskan dengan menggunakan angka-angka ataupun kata-kata. Penelitian ini menggunakan penelitian deskriptif karena adanya hipotesis untuk dapat menjawab masalah yang ada, terdapat masalah, menggunakan metode survey, dan dapat menggunakan teknik kuantitatif. Menurut Kasiram (2008) penelitian kuantitatif merupakan proses untuk menemukan suatu pengetahuan dimana hasil yang didapat berupa data angka yang sebagai alat untuk menganalisis keterangan mengenai hal apa yang ingin diketahui. Menurut Malhotra (2004) sampel adalah sebuah kelompok yang dipilih untuk serta dalam penelitian. Menurut Roscoe dalam Sugiyono (2012:91), kelayakan suatu ukuran sampel di dalam penelitian antara 30 sampai dengan 500 Ukuran ini merupakan ukuran yang paling tepat untuk melakukan sebuah penelitian menurut Frankel dan Wallen (1993) mengemukakan bahwa besaran jumlah sampel minimum untuk penelitian deskriptif adalah sebanyak 100 responden, sehingga dalam penelitian ini peneliti menetapkan untuk menggunakan sampel sebanyak 100 responden dengan kriteria Mahasiswa Universitas Tarumanagara. Metode pengambilan sampel yang dilakukan di dalam penelitian ini adalah non-probability sampling. Karena adanya keterbatasan waktu maka penelitian ini menggunakan teknik sampel judgemental sampling dengan menggunakan google form secara elektronik. Ukuran ini merupakan ukuran yang paling tepat untuk melakukan sebuah penelitian menurut Frankel dan Wallen (1993) mengemukakan bahwa besaran jumlah sampel minimum untuk penelitian deskriptif adalah sebanyak 100 responden, sehingga dalam penelitian ini peneliti menetapkan untuk menggunakan sampel sebanyak 100 responden dengan kriteria Mahasiswa Universitas Tarumanagara.

\section{HASIL ANALISIS DATA}

Dari 100 orang responden, $60 \%$ berjenis kelamin perempuan dan $40 \%$ berjenis kelamin laki-laki. Berdasarkan usia, responden berusia kurang dari 17-19 tahun sebanyak 2\%, usia 2022 tahun sebanyak 80\%, usia 23-25 tahun sebanyak 13\%, dan usia >20 tahun sebanyak 5\%. Berdasarkan latar belakang jurusan $98 \%$ dari responden memiliki jutusan Manajemen dan 2\% dari responden memiliki jurusan Akuntansi.

Berdasarkan pengolahan hasil tanggapan responden, diperoleh hasil pengujian outer model. Pengujian validitas yaitu Average Variance Extracted (AVE) sebagai acuan dasar dan telah memenuhi kriteria yaitu persyaratan nilai minimum 0.5 sehingga data telah dinyatakan valid. Selanjutnya, hasil nilai outer loadings dari seluruh indikator telah melebihi 0.7, dimana suatu data memiliki validitas konvergen yang baik apabila berada pada angka diatas 0.7. Untuk pengujian Fornell-Larcker, variabel penelitian telah memenuhi kriteria dengan melihat angka setiap variabel yang memiliki angka korelasi konstruk yang lebih besar dibandingkan nilai antarkonstruk lainnya. Hasil pengujian cross loadings pada masing-masing indikator variabel memiliki nilai yang lebih tinggi daripada nilai variabel lain terhadap variabel itu sendiri. Dengan demikian, data telah memenuhi standar analisis cross loadings. Kemudian 
pada pengujian reliabilitas, kriteria data yang dapat diandalkan yaitu berada diatas nilai minimum 0.6 untuk pengukuran Cronbach's Alpha dan Composite Reliability. Hasil analisis setiap variabel dalam penelitian ini telah memiliki angka diatas 0.6 untuk, oleh sebab itu data dapat dinyatakan reliabel.

Untuk pengujian koefisien determinasi $\left(R^{2}\right)$ memiliki nilai 0,453. Maka variabel Niat Berwirausaha dapat dijelaskan sebesar $45,3 \%$ oleh ketiga variabel independen dalam penelitian ini, sedangkan sisanya 54,7\% dapat dijelaskan melalui variabel lain yang tidak ditelaah dalam penelitian ini. Selanjutnya, pengujian $\mathrm{Q}$-Square $\left(\mathrm{Q}^{2}\right)$ memiliki nilai sebesar 0,283 sehingga dapat dinilai bahwa terdapat relevansi prediktif dari pengaruh variabel independen terhadap variabel dependen secara baik. Dengan nilai 0,283 maka $\mathrm{Q}-$ Square $\left(\mathrm{Q}^{2}\right)$ tergolong memiliki tingkat prediksi pada golongan baik. Selanjutnya, nilai uji kecocokan model yang telah digitung secara manual memiliki nilai 1,0585. Maka, uji Goodness of Fit $(\mathrm{GoF})$ tergolong besar yaitu berada diatas angka 0,36. Kemudian pengujian hipotesis (path coefficient) dilakukan untuk menilai hubungan antar variabel agar dapat mencapai suatu kesimpulan apakah hipotesis diterima atau tidak. Dalam mengukur path coefficient, nilai tstatistik harus melebihi 1,96 atau p-value dibawah 0,05 agar suatu hipotesis dinyatakan signifikan. Hasil analisis data menunjukkan bahwa seluruh variabel independen memiliki pengaruh yang signifikan terhadap timbulnya Niat berwirausaha, berikut hasil pengujian path coefficient dikemukakan pada tabel 1.

Tabel 1. Pengujian Path Coefficient

\begin{tabular}{|l|c|c|}
\hline Variabel & T-Statistik & P-Values \\
\hline Kreativitas ->Niat berwuirausaha & 1.477 & 0.140 \\
\hline Sikap terhadap kewirausahaan-> Niat berwirausaha & 2.841 & 0.007 \\
\hline Orientasi kewirausahaan -> Niat berwirausaha & 2.696 & 0.005 \\
\hline
\end{tabular}

* Sumber: olahan data SmartPLS versi 3.00

\section{DISKUSI}

Pernyataan pada hipotesis pertama $\left(\mathrm{H}_{1}\right)$ Terdapat pengaruh yang positif antara Kreativitas terhadap Niat berwirausaha pada mahasiswa Univeristas Tarumanagara. Menurut Dollinger et al. ( 2005), Kreativitas berdasarkan definis di atas adalah individu yang aktif mencari informasi internalisasi kemungkinan baru dan menarik bagi siapa mereka mungkin menjadi yang dapat meningkatkan kreativitas mereka. Di dukung oleh (Runco and Jaeger, 2012) Kreativitas biasanya digambarkan sebagai kemampuan untuk menciptakan objek atau ide yang baru dan efektif. Sedangkan menurut Binnewies et al. (2007) mengemukakan bahwa inisiatif pribadi (suatu konstruk yang berkaitan dengan proaktif) adalah penting pada awal proses kreatif dan untuk kreativitas ide. Berdasarkan definisi-definisi yang ada dapat disimpulkan bahwa Kreativitas adalah salah satu cara yang dalam mengembangkan ide-ide berwirausaha. Jadi, dapat disimpulkan bahwa variabel kreativitas tidak pengaruh signifikan terhadap niat berwirausaha pada Mahasiswa Universitas Tarumanagara. Berikutnya, pernyataan hipotesis kedua $\left(\mathrm{H}_{2}\right)$ Terdapat pengaruh yang positif antara sikap terhadap kewirausahaan terhadap Niat berwirausaha pada mahasiswa Univeristas Tarumanagara. Menurut (Kirkwood, 2007) Sikap terhadap kewirausahaan akan secara positif terkait dengan niat kewirausahaan individu, sikap dan niat wirausaha memberikan bukti tentang pentingnya relatif interaksi antara panutan dan niat wirausaha. Menurut (Ajzen, 1991)Teori perilaku terencana berpendapat bahwa sikap adalah prekursor niat yang mendahului perilaku. 
Berdasarkan definisi-definisi yang ada dapat disimpulkan bahwa Sikap terhadap kewirausahaan adalah salah satu cara yang penting dalam mengembangkan niat berwirausaha. Jadi, dapat disimpulkan bahwa variabel sikap terhadap kewirausahaan memiliki pengaruh positif terhadap niat berwirausaha pada Mahasiswa Universitas Tarumanagara. Pernyataan hipotesis ketiga $\left(\mathrm{H}_{3}\right)$ menghasilkan konklusi bahwa terdapat pengaruh positif dari entrepreneurship education terhadap timbulnya entrepreneurial passion. Menurut (Rauch et al., 2009; Wiklund and Shepherd, 2003) Kemajuan penting dalam pemahaman kita tentang perilaku kewirausahaan adalah orientasi kewirausahaan (EO) (Miller, 1983), yang disebut orientasi kewirausahaan adalah memungkinkan wirausahawan mencapai keuntungan ekonomi dan non-ekonomi untuk organisasi mereka. Orientasi kewirausahaan (entrepreneurial orientation) adalah orientasi perusahaan yang memiliki prinsip pada upaya untuk mengidentifikasi dan mengeksploitasi kesempatan (Lee \& Chu, 2011). Ahimbisibwe dan Abaho (2013) menyatakan bahwa perusahaan yang memiliki orientasi kewirausahaan yang kuat, akan lebih berani untuk mengambil risiko,dan tidak cuma bertahan pada strategi masa lalu. Pada lingkungan yang dinamis seperti saat ini, orientasi kewirausahaan jelas merupakan hal yang sangat penting bagi kelangsungan hidup perusahaan. Di dukung oleh Patel dan D'Souza (2009) mendefinisikan orientasi kewirausahaan sebagai orientasi untuk menjadi yang pertama dalam hal inovasi di pasar, memiliki sikap untuk mengambil risiko, dan proaktif terhadap perubahan yang terjadi pasar. Dimensi kunci yang dapat menentukan karakteristik suatu orientasi kewirausahaan yaitu inovatif (innovativenes), pengambilan resiko (risk-taking), sikap proaktif (proactiveness), agresivitas kompetitif (competitive aggressiveness), dan otonomi (autonomy). Berdasarkan definisi-definisi yang ada dapat disimpulkan bahwa Orientasi Kewirausahaan merupakan hal yang penting dalam berwirausah. Jadi, dapat disimpulkan bahwa variabel orientasi kewirausahaan memiliki pengaruh positif terhadap niat berwirausaha pada Mahasiswa Universitas Tarumanagar

\section{PENUTUP}

Setelah memperoleh dan melakukan analisis data serta pembahasan, maka kesimpulan yang dihasilkan adalah Kreativitas tidak memiliki pengaruh yang positif terhadap niat berwirausahakarna tidak berpengaruh secara signifikan sedangkan Sikap terhadap kewirausahaan memiliki pengaruh yang positif terhadap niat berwirausaha dan Orientasi kewirausahaan memiliki pengaruh yang positif terhadap niat berwirausaha karnda dapat meningkatkan niat dalam berwirausaha

Terdapat beberapa saran yang disampaikan dengan harapan akan bermanfaat bagi lembaga pendidikan dan peneliti selanjutnya yang akan melakukan studi dengan tema yang berkaitan dengan topik penelitian ini Bagi Universitas Tarumanagara disarankan agar lebih meningkatkan minat dan wawasan Mahasiswa/i mengenai ilmu kewirausahaan dengan cara melakukan praktek kewirausahaan agar membangun niat berwirausaha dengan melakukan kolaborasi dengan para wirausaha atau dengan para professional untuk memberikan pemikiran yang harus dimiliki Mahasiswa untuk bekal membangun wirausaha dalam bentu seminar, workshop atau project kewirausahaan selain itu bagi seluruh Mahasiswa/i Universitas Tarumanagara disarankan agar lebih tekun dalam meningkatkan potensi kewirausahaan yang dimiliki dengan cara mengikuti seminar dan workshop kewirausaahn dari dalam dan luar Universitas membaca buku-buku kewirausahaan dan berdiskusi dengan relasi yang sudah mempraktekan ilmu kewirausahaan dan untuk peneliti selanjutnya, diharapkan dapat menggunakan variabel-variabel independen yang lain seperti proactivity, 
entrepreneurs education, entrepreneurial attributes, dan social context and self-efficacy. Dan juga memperluas jumlah sampel dan tidak terikat hanya pada satu profil responden agar dapat diperoleh hasil yang lebih optimal dan lebih bervariasi dari penelitian sebelumnya. Penelitian ini memiliki beberapa keterbatasan, yaitu Penelitian ini hanya menggunakan empat variabel yang terdiri dari tiga variabel independen yakni kreativitas, sikap terhadap kewirausahaan, dan niat berwirausaha. Variabel dalam penelitian ini masih sangat terbatas sehingga dirasa masih kurang karena masih banyak variabel lainnya yang dapat mempengaruhi niat berwirausaha. Selain itu adanya kendala Covid-19 yang menjadi masalah utama di tahun 2020 menyebabkan peneliti sulit untuk mendapatkan jumlah responden yang lebih besar dan menyebabkan kendala dalam penyebaran kuesioner, yaitu peneliti hanya dapat menyebarkan kuesioner melalui media elektronik saja.

\section{DAFTAR PUSTAKA}

Ahimbisibwe, Godwin dan Abaho Ernst. (2013). Export Entrepreneurial Orientation and ExportPerformance of SMEs in Uganda. Global Advanced Research Journal of Managementand Business Study, Volume 2(1), January

Ajzen, I. (1991), "The theory of planned behavior", Organizational Behavior \& Decision Processes, Vol. 50, pp. 179- 211.

Binnewies, C., Ohly, S. and Sonnentag, S. (2007), "Taking personal initiative and communicating about ideas: what is important for the creative process and for idea creativity?", European 615 Journal of Work and Organizational Psychology, Vol. 16 No. 4 , pp. $432-55$

Bird, B. (1988), "Implementing entrepreneurial ideas: the case for intention", Academy of Management Review, Vol. 13 No. 3, pp. 442-453.

Dollinger, SJ, Dollinger, SMC dan Centeno, L. (2005), "Identitas dan kreativitas", Identitas:An International Journal of Teori dan Penelitian, Vol. 5, pp. 315-39.

Douglas, E.J. and Shepherd, D.A. (2002), "Self-employment as a career choice: attitudes, entrepreneurial intentions, and utility maximization", Entrepreneurship Theory \& Practice, Vol. 26 No. 3, pp. 81- 90.

Fatoki, O.O. (2010), "Graduate entrepreneurial intention in South Africa: motivations and obstacles", International Journal of Business and Management, Vol. 5 No. 9, pp. 87-98.

Frankel, Jack R \& Norman E. Wallen. (1993). How to design and Evaluate Research in Education. 2nd edition. New York: McGraw hill Inc

Giacomin, O., Janssen, F., Pruett, M., Shinnar, R.S., Llopis, F. and Toney, B. (2011), "Entrepreneurial intentions, motivations and barriers: differences among American, Asian and European students", International Entrepreneurship and Management Journal, Vol. 7 No. 2, pp. 219-238.

Hamidi, D., Wennberg, K. and Berglund, H. (2008), "Creativity in entrepreneurship education”, Journal of Small Business and Enterprise Development, Vol. 5 No. 2, pp. 304-320.

Hayton, J.C. and Cholakova, M. (2012), "The role of affect in the creation and intentional pursuit of entrepreneurial ideas", Entrepreneurship Theory and Practice, Vol. 36 No. $1, \mathrm{pp} .41-68$.

Heinonen, J. and Poikkijoki, S.-A. (2006), "An entrepreneurial-directed approach to entrepreneurship education: mission impossible?", The Journal of Management Development, Vol. 25 No. 1, pp. 80-94. 
Kartika,et.al., (2019)" Sustainable Entrepreneurial Intention: The Perceived Of Triple Bottom Line Among Female Students "Jurnal Manajemen/Volume XXIII, No. 02, June 2019: 168-190

Kasiram, M. (2008). Metodologi Penelitian. Malang: UIN-Malang Pers.

Kirkwood, J. (2007), "Memicu semangat kewirausahaan: adalah peran orang tua bermain gender?",International Journal of Wirausaha Perilaku \& Research, Vol. 13 No 1, pp. $39-59$

Kirzner, I. (1978), Competition and Entrepreneurship, University of Chicago Press, Chicago, IL.

Kolvereid, L. and Isaksen, E. (2006), "New business start-up and subsequent entry into selfemployment", Journal of Business Venturing, Vol. 21 No. 6, pp. 866-885.

Lee,S.H.and Wong,P.K.(2004), "An exploratory study of technopreneurial intention: a career anchor prespective", Journal of Bussines Venturing, Vol.19 No.1,pp.7-28.

Lee, Ting Ko dan Wenyi $\mathrm{Cu}$. (2011). Entrepreneurial Orientation and Competitive Advantage:The Mediation of Resource Value and Rareness. African Journal of BusinessManagement, Volume 5 (33)

Lumpkin, G.T. and Dess, G.G. (1996), "Clarifying the entrepreneurial orientation construct and linking it to performance", Academy of Management Review, Vol. 21 No. 1, pp. $135-172$

Malhotra, N. K. (2004). Riset Pemasaran, Pendekatan Terapan. Edisi Bahasa Indonesia, PT. Indeks Kelompok Gramedia, Jakarta.

Miller, D. (1983), "The correlates of entrepreneurship in three types of firms", Management science, Vol. 29 No. 7, pp. 770-791.

Molaei, R. , Zali, M.R. , Mobaraki, M.H. and Farsi, J.Y. (2014), "The impact of entrepreneurial ideas and cognitive style on students entrepreneurial intention", Journal of Chinese Entrepreneurship, Vol. 6 No. 2, p. 3.

Nuringsih et.al., (2020) "The Propensity for Social Entrepreneurship

During the Coronavirus Outbreak". Jurnal Manajemen/Volume XXIV, No. 02, June 2020: 174-193

Patel, Pankaj, C dan Rodney D’Souza. (2009). Leveraging Entrepreneurial Orientation to EnhanceSME Export Performance. Small Business Research Summary, 337

Pulka, B.M., Rikwentishe, R. and Ibrhain, B. (2014), "Evaluation of students' attitude towards entrepreneurship education in some selected universities in North East Nigeria", Global Journal of Management and Business Research, Vol. 14 No. 8, pp. 18.

Punaji, S. (2010). Metode Penelitian Pendidikan dan Pengembangan .Jakarta Kencana.

Rae, D. (2007), Entrepreneurship: From Opportunity to Action, Palgrave Macmillan, New York, NY.

Rauch, A., Wiklund, J., Lumpkin, G.T. and Frese, M. (2009), "Entrepreneurial orientation and business performance: an assessment of past research and

Runco, M.A. and Jaeger, G.J. (2012), "The standard definition of creativity", Creativity Research Journal, Vol. 24 No. 1, pp. 92-96, doi: 10.1080/10400419.2012.650092 (accessed 18 November 2019).

Schumpeter, J. (1928), “The instability of capitalism”, Economic Journal, 
Simon, M., Stachel, C. and Covin, J.G. (2011), "The effects of entrepreneurial orientation and commitment to objectives on performance", New England Journal of Entrepreneurship, Vol. 14 No. 2, pp. 9-17.

Sugiono. (2001). Metode Penelitian, Bandung: Alfabeta

Sugiyono. (2012). Metode Penelitian Pendidikan. Bandung: Alfabeta

Thompson, E.R. (2009), "Individual entrepreneurial intent: construct clarification and development of an internationally reliable metric", Entrepreneurship Theory and Practice, Vol. 33 No. 3, pp. 669-694.

Wang, C.L. (2008), "Entrepreneurial orientation, learning orientation and firm performance", Entrepreneurship Theory and Practice, Vol. 32 No. 4, pp. 635-656. 